This Accepted Author Manuscript is copyrighted and published by Elsevier. It is posted here by agreement between Elsevier and University of Brasilia. Changes resulting from the publishing process - such as editing, corrections, structural formatting, and other quality control mechanisms - may not be reflected in this version of the text. The definitive version of the text was subsequently published in [Theriogenology, Volume 61, Issues 2-3, 15 January 2004, Pages 461-472, doi:10.1016/S0093-691X(03)00226-7].You may download, copy and otherwise use the AAM for non-commercial purposes provided that your license is limited by the following restrictions:

(1) You may use this AAM for non-commercial purposes only under the terms of the CC-BY-NCND license.

(2) The integrity of the work and identification of the author, copyright owner, and publisher must be preserved in any copy.

(3) You must attribute this AAM in the following format: [agreed attribution language, including link to CC BY-NC-ND license + Digital Object Identifier link to the published journal article on Elsevier's ScienceDirect ${ }^{\circledR}$ platform].

Este Manuscrito do Autor Aceito para Publicação (AAM) é protegido por direitos autorais e publicado pela Elsevier. Ele esta disponível neste Repositório, por acordo entre a Elsevier e a Universidade de Brasília. As alterações decorrentes do processo de publicação - como a edição, correção, formatação estrutural, e outros mecanismos de controle de qualidade - não estão refletidas nesta versão do texto. A versão definitiva do texto foi posteriormente publicado em [Theriogenology, Volume Volume 61, Número 2-3, 15 de Janeiro de 2004, Páginas 461-472, doi:10.1016/S0093-691X(03)00226-7]. Você pode baixar, copiar e utilizar de outra forma o AAM para fins não comerciais, desde que sua licença seja limitada pelas seguintes restrições:

(1) Você pode usar este AAM para fins não comerciais apenas sob os termos da licença CC- BYNC-ND.

(2) A integridade do trabalho e identificação do autor, detentor dos direitos autorais e editor deve ser preservado em qualquer cópia.

(3) Tem de atribuir este AAM no seguinte formato: [acordo na linguagem atribuída, incluindo o link para CC BY-NC-ND licença Digital + DOI do artigo publicado na revista Elsevier ScienceDirect ${ }^{\circledR}$ da plataforma]. 


\section{Effects of lowered temperatures and media on short-term preservation of zebu (Bos indicus) preantral ovarian follicles}

Carolina M Lucci

Mirella A Kacinskis

Rodolfo Rumpf

Sônia N Báo

\section{Abstract}

The maintenance of follicle quality during the transportation of ovaries is essential for the successful cryopreservation and in vitro development of preantral follicles. The objective of this study was to evaluate the effect of cooling ovarian tissue on the conservation of zebu cow preantral follicles. Ovarian pieces were immersed in saline or coconut water (CW) solutions and maintained at 4 or $20^{\circ} \mathrm{C}$ for 6,12 , or $18 \mathrm{~h}$. Preantral follicles were evaluated by histology and transmission electron microscopy. Storage of ovarian pieces at $20{ }^{\circ} \mathrm{C}$ for 12 or $18 \mathrm{~h}$ significantly reduced the percentage of morphologically normal follicles compared to controls. In contrast, conservation at $4{ }^{\circ} \mathrm{C}$ for up to $18 \mathrm{~h}$ and at $20^{\circ} \mathrm{C}$ for up to $6 \mathrm{~h}$ kept the percentage of normal follicles similar to controls. However, the type of solution that the ovaries were immersed in had little effect on the results. Decreased cellular metabolism probably accounted for better preservation of preantral follicles at $4{ }^{\circ} \mathrm{C}$. In conclusion, zebu cow ovaries were successfully stored at $4{ }^{\circ} \mathrm{C}$ for up to $18 \mathrm{~h}$ with no morphological damage to preantral follicles. However, at $20^{\circ} \mathrm{C}$, ovaries could only be stored for $6 \mathrm{~h}$.

Keywords: Zebu cows; Preantral follicles; Ovaries; Storage; Morphology

\section{Introduction}

In the last few years, the biotechnology involved in the manipulation of oocytes enclosed in preantral follicles has received much attention. The use of oocytes from preantral follicles in reproductive techniques may offer new ways of improving germplasm banks and propagating valuable animal stocks and endangered species. However, especially in the case of farm and endangered animals, the ovarian donor is commonly far away from the laboratory. The preservation of preantral follicles during the transportation of ovaries is crucial to ensure follicular quality at the onset of cryopreservation or in vitro culture. Therefore, there is an obvious need to develop guidelines for optimum storage methods during transportation, and to determine the maximum interval between ovary collection and successful gene banking.

Some experiments have been conducted to evaluate the effects of storage temperatures and media on the quality of preantral follicles [1] and [2]. In general, researchers found storage temperatures of 4 and $20^{\circ} \mathrm{C}$ to be more suitable than $39{ }^{\circ} \mathrm{C}$ (body temperature) 
for the preservation of the normal morphology of sheep [3] and goat [1], [2] and [4] preantral follicles in situ. Storage at $20{ }^{\circ} \mathrm{C}$ has proved suitable for the preservation of preantral follicles for up to $4 \mathrm{~h} \mathrm{[1]} \mathrm{and} \mathrm{[4]} \mathrm{and} 4{ }^{\circ} \mathrm{C}$ was effective for 12 or $24 \mathrm{~h}$ of preservation [1], [2] and [4], depending on the storage media. Media tested for the preservation of preantral follicles in ovarian pieces include saline solution (SS) [2] and [3], Braun-Collins solution [1], coconut water (CW) [1], [2] and [3], and M199 (with or without indole-3-acetic acid) [4]. However, all these studies were performed in small ruminant (sheep and goat) ovaries, and nothing is known about preserving preantral follicles in zebu cow ovaries.

The present study was conducted to evaluate the effect of preserving preantral follicles present in zebu cows ovaries in two different media, at different temperatures and storage intervals. The chosen temperatures $\left(4\right.$ and $20^{\circ} \mathrm{C}$ ) were those that yielded the best results in previous studies [1], [2], [3] and [4], and the three storage times (6, 12, and $18 \mathrm{~h})$ were taken at regular intervals of $6 \mathrm{~h}$.

\section{Materials and methods}

\subsection{Experimental protocol}

Four ovaries (from four different animals and without $\mathrm{CL}$ or dominant follicle) from zebu cows (Nelore) were collected at a local abattoir. Each ovary was divided into 13 pieces of similar cortex area. One ovarian piece from each ovary was chosen randomly. A small fragment from each of those pieces was removed for electron microscopy, and the remainder immediately fixed for histology (control). The other 12 pieces were randomly distributed into tubes containing $10 \mathrm{ml}$ of stabilized CW or sterile SS and stored at 4 or $20^{\circ} \mathrm{C}$ for 6,12 , or $18 \mathrm{~h}$ (Fig. 1). CW was obtained from 6-month-old fruits of the Green Beach variety (Cocus nucifera). Its osmolarity and $\mathrm{pH}$ were stabilized by mixing two parts filtered $\mathrm{CW}$, one part distilled water, and one part $5 \%$ sodium citrate solution (final osmolarity, $300 \mathrm{mOsm}$ and $\mathrm{pH}$ 6.8) [5]. The composition of CW [6] is shown in Table 1. The temperature was maintained with the use of thermos flasks and measured at the beginning of the experiment and every $6 \mathrm{~h}$ to the end of the treatments. Each treatment was replicated four times. 


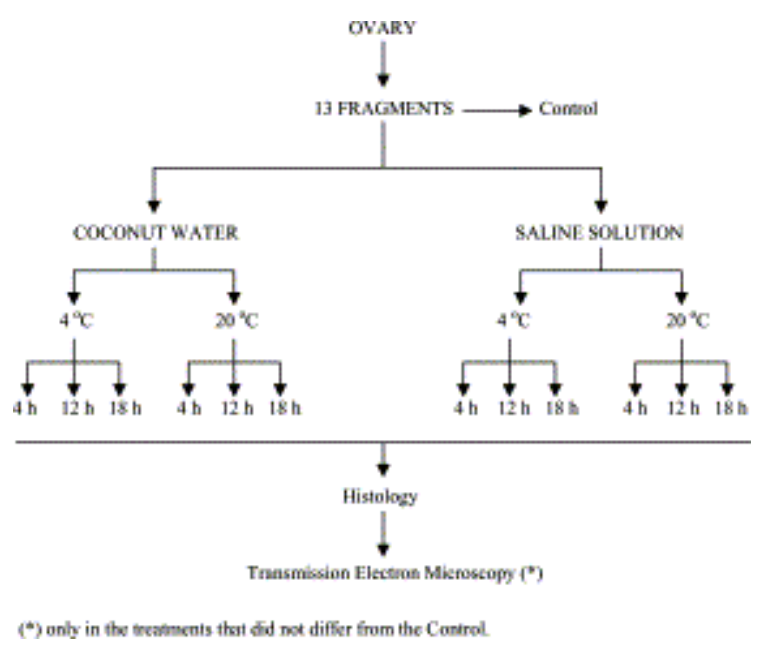

Fig. 1. Experimental protocol for preservation of zebu preantral follicles in ovarian pieces.

\subsection{Histological analysis}

To evaluate the morphology of the zebu preantral follicles, ovarian pieces were processed (at the end of the treatments) as follows. A small fragment of each ovarian piece was removed for electron microscopy. The remainder was fixed in Carnoy fixative for $4 \mathrm{~h}$, dehydrated in ethanol, clarified with xylene, embedded in paraffin wax, and sectioned at $5 \mu \mathrm{m}$ thickness. The sections were stained with Periodic Acid Schiff and hematoxylin (PAS staining system, Sigma Diagnostics, Inc., St. Louis, MO, USA), and examined under a Zeiss Axiophot light microscope (Oberkochen, Germany) at 200 and 400x.

Preantral follicles were classified as primordial (one layer of flattened or flattenedcuboidal granulosa cells around the oocyte), primary (one layer of cuboidal granulosa cells around the oocyte) and secondary (two or more layers of cuboidal granulosa cells around the oocyte), according to their developmental stage [7]. Follicle quality was concurrently evaluated. Preantral follicles were classified according to their morphological appearance as morphologically normal (containing a healthy and intact oocyte, with a round nucleus and evident nucleolus, surrounded by well-organized granulosa cells without pycnotic nuclei), degenerate Type 1 (containing a somewhat shrunken oocyte with pycnotic nucleus, but normal granulosa cells) and degenerate Type 2 (containing a shrunken oocyte, disorganized granulosa cells and low cellular density). The percentages of each kind of follicle were calculated for each ovarian piece. 
Table 1

Composition of coconut water from 6-month-old fruits

\begin{tabular}{|c|c|}
\hline \multicolumn{2}{|l|}{ Component } \\
\hline \multicolumn{2}{|l|}{ Amino acids $(\mu \mathrm{g} / \mathrm{ml})$} \\
\hline Aspartic acid & 5.4 \\
\hline Glutamic acid & 78.7 \\
\hline Serine & 65.8 \\
\hline Glycine & 13.9 \\
\hline Asparagine & 10.4 \\
\hline Threonine & 26.3 \\
\hline Alanine & 177.1 \\
\hline Glutamine & 13.4 \\
\hline Lysine & 22.5 \\
\hline Arginine & 16.8 \\
\hline Proline & 21.6 \\
\hline Valine & 15.1 \\
\hline Leucine & 31.7 \\
\hline Phenylalanine & 10.2 \\
\hline Tyrosine & 3.1 \\
\hline Amino butyric acid & 168.8 \\
\hline Homo serine & 5.2 \\
\hline Histidine, methionine and hydroxy-proline & (Traces) \\
\hline \multicolumn{2}{|l|}{ Carbohydrates (mg/ml) } \\
\hline Sucrose & 8.9 \\
\hline Glucose & 2.46 \\
\hline Fructose & 2.51 \\
\hline \multicolumn{2}{|l|}{ Vitamins (mg/ml) } \\
\hline Nicotinic acid & 0.64 \\
\hline Pantothenic acid & 0.52 \\
\hline Biotin & 0.02 \\
\hline Riboflavin & 0.01 \\
\hline Folic acid & 0.003 \\
\hline Thiamine and pyridoxine & (Traces) \\
\hline \multicolumn{2}{|l|}{ Minerals $(\mathrm{mg} / 100 \mathrm{ml})$} \\
\hline Potassium & 312.0 \\
\hline Chlorine & 183.0 \\
\hline Sodium & 105.0 \\
\hline Phosphorus & 37.0 \\
\hline Magnesium & 30.0 \\
\hline Sulfur & 24.0 \\
\hline Iron & 0.1 \\
\hline Copper & 0.04 \\
\hline Calcium & (Traces) \\
\hline
\end{tabular}

Source: Laguna and Nunes [6]

\subsection{Ultrastructural analysis}

To better evaluate follicular quality, an ultrastructural analysis was performed in preantral follicles from the control treatment, as well as from the treatments that did not differ from the control in the histological analysis ( $n=6$ follicles per group). In brief, small pieces of ovarian cortex were fixed in $2 \%$ paraformaldehyde, $2.5 \%$ glutaraldehyde, and $0.1 \mathrm{M}$ sodium cacodylate buffer $\mathrm{pH} 7.2$, for $3 \mathrm{~h}$ at room temperature or overnight at $4{ }^{\circ} \mathrm{C}$. After washing the ovarian pieces with sodium cacodylate buffer, they were postfixed in a solution containing $1 \%$ osmium tetroxide, $0.8 \%$ potassium ferricyanide, and $5 \mathrm{mM}$ calcium chloride in $0.1 \mathrm{M}$ sodium 
cacodylate buffer. Subsequently, the samples were dehydrated in acetone and embedded in Spurr. Semi-thin sections $(3 \mu \mathrm{m})$ were stained with Toluidine Blue. Thin sections $(70 \mathrm{~nm})$ were contrasted with uranyl acetate and lead citrate, and examined in a Jeol JEM 100C (Jeol, Tokyo, Japan) transmission electron microscope at 1000-10,000x. Only follicles with normal morphology at semi-thin sections were evaluated for ultrastructural organization. All electron microscopy reagents were purchased from Electron Microscopy Sciences (Ft. Washington, PA, USA).

\subsection{Statistical analysis}

The effect of preservation solution, temperature, and incubation time on the percentage of normal follicles, as well as the interactions among them, was analyzed by ANOVA ( $2 \times 2 \times 3$ factorial design). Fisher's PLSD post hoc test was used to make individual comparisons between each treatment and the control and among treatments. Analysis of variance and Fisher's PLSD test were also used to compare the percentage of degenerate Type 1 and Type 2 follicles within each treatment. The percentages of degenerated primordial, primary, and secondary follicles were compared by Chi-square. Analysis was performed using the StatView computer system for Windows (SAS Institute Inc., Cary, NC, USA). Percentages were subjected to arcsine transformation prior to analysis and data are presented as mean $\pm S$.D. Differences were considered significant when $P<0.05$.

\section{Results}

A total of 4901 preantral follicles ( $377 \pm 114$ per treatment, $129 \pm 81$ per ovarian piece) were analyzed. Follicles classified as morphologically normal, degenerate Type 1 and degenerate Type 2 are shown in Fig. 2a-c, respectively). 

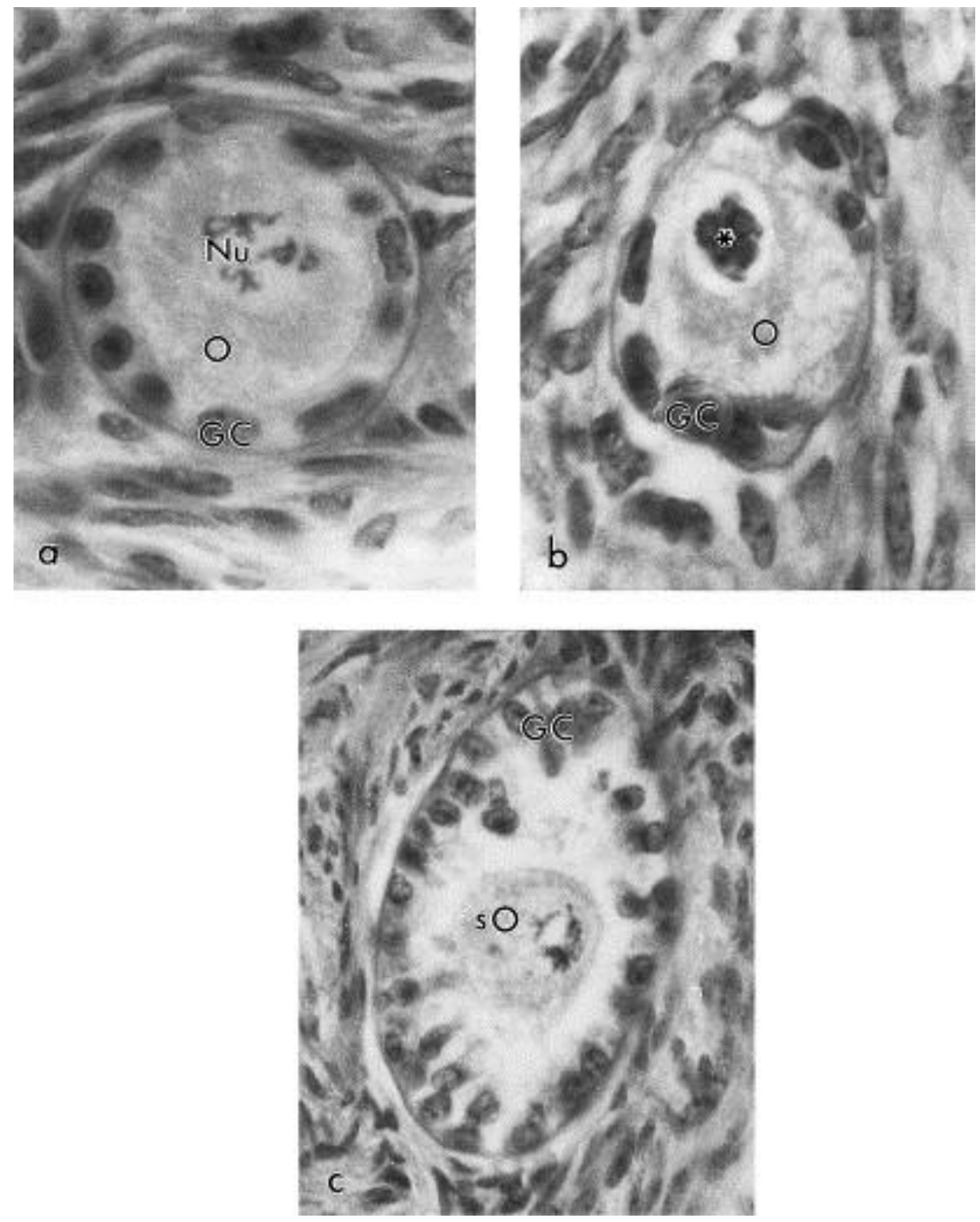

Fig. 2. Follicle classification according to morphological appearance. (a) A morphologically normal follicle (710x), with a round oocyte $(0)$ surrounded by well-organized granulosa cells (GC); Nu, Nucleus with evident nucleolus; (b) a degenerate Type 1 follicle (710x), with a degenerate oocyte $(\mathrm{O})$ with pycnotic nucleus $(*)$ and normal granulosa cells $(\mathrm{GC})$; and (c) a degenerate Type 2 follicle (450x), with a shrunken oocyte ( $\mathrm{sO}$ ) and disorganized granulosa cells (GC); note the low cellular density. PAS-hematoxylin stained.

In ovarian pieces stored at $4{ }^{\circ} \mathrm{C}$ for up to $18 \mathrm{~h}$ and at $20^{\circ} \mathrm{C}$ for up to $6 \mathrm{~h}$, in either solution, the percentage of morphologically normal preantral follicles (MNPF) was similar to controls (i.e. in vivo conditions). In contrast, the storage of ovarian pieces in either solution at $20^{\circ} \mathrm{C}$ for 12 or $18 \mathrm{~h}$ significantly decreased the percentage of MNPF compared to control (Fig. 3). Differences in the ability of the two solutions to maintain follicle integrity was only manifest at a temperature of $20^{\circ} \mathrm{C}$ and storage time of $12 \mathrm{~h}$. Under these conditions $\mathrm{CW}$ was better than SS, but both treatments were significantly worse than the control (Fig. 3). At 
temperatures and storage times where the percentage of MNPF was similar to control, there was no significant difference between the two solutions.

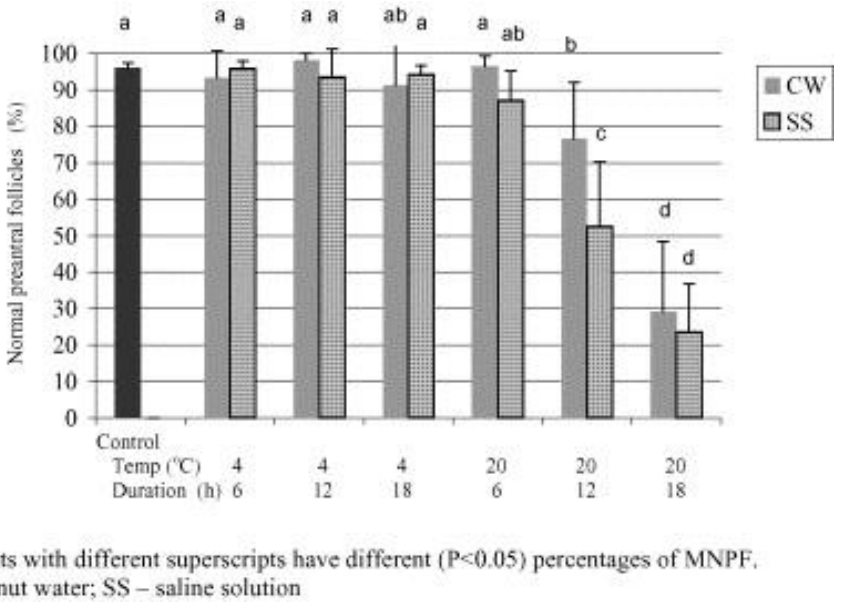

Fig. 3. Mean ( \pm S.D.) percentage of morphologically normal preantral follicles (MNPF) in the control and 12 treatment groups.

Ultrastructural analysis confirmed the integrity of preantral follicles stored at $4{ }^{\circ} \mathrm{C}$ for up to $18 \mathrm{~h}$ (in either solution). Preantral follicles stored either in CW (Fig. 4b) or in SS (Fig. 4c) at $4{ }^{\circ} \mathrm{C}$ for $18 \mathrm{~h}$ had very similar ultrastructure compared to the control (Fig. 4a). Briefly, wellpreserved follicles had a round oocyte tightly connected to the surrounding granulosa cells. Numerous round and elongated mitochondria, a few smooth endoplasmic reticulum cisternae and a variable number of vesicles were observed spreading in the cytoplasm of oocytes, which had a fine granulation. The nuclei of oocytes were large and usually round, well delimited by the nuclear envelopes, and one or two nucleoli could be identified in each nucleus. Granulosa cells had an irregular-shaped nucleus, with peripheral agglomerates of dense chromatin. A great number of rough endoplasmic reticulum cisternae, Golgi apparatus and mitochondria were present in the cytoplasm of granulosa cells. Follicles were always surrounded by a basement membrane. 

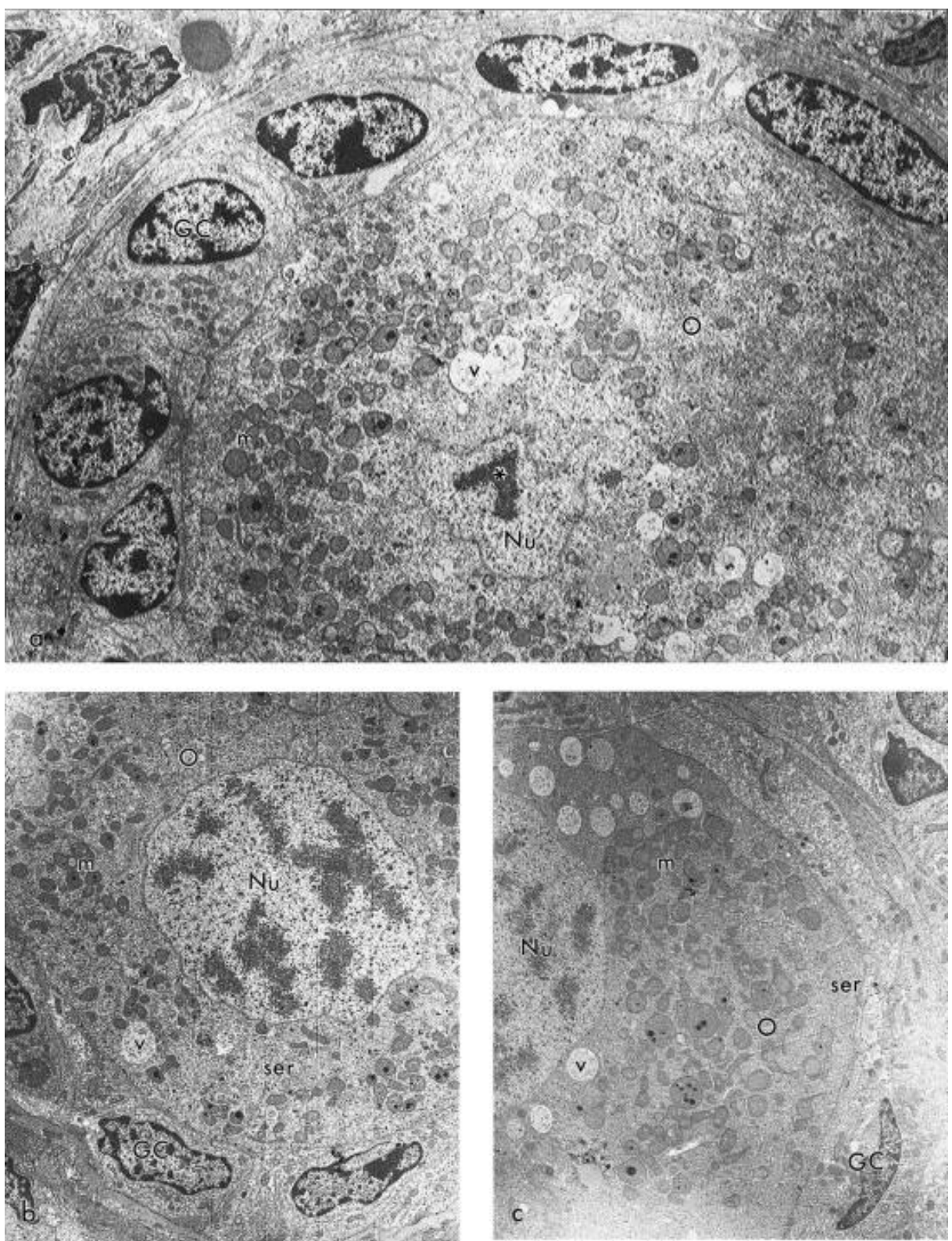

Fig. 4. Electron micrographs showing preantral follicles (a) in the control group (3500x), and preserved in (b) coconut water (2800x), and (c) saline solution at $4{ }^{\circ} \mathrm{C}$ for $18 \mathrm{~h}(2800 \mathrm{x})$. Note the similar and well-preserved ultrastructure of all three follicles. GC, granulosa cells; $\mathrm{O}$, oocyte; $\mathrm{Nu}$, nucleus; $\mathrm{m}$, mitochondria; ser, smooth endoplasmic reticulum; v, vesicles; (*), nucleolus.

Combined for all treatments, $18.4 \%$ (904/4901) of the analyzed follicles were degenerate, of which 4.6 (225/4901) and 13.8\% (679/4901) were degenerate Type 1 and Type 2 , respectively. Table 2 shows the mean ( \pm S.D.) percentage of degenerate Type 1 and Type 2 follicles in each treatment. In general, the percentage of degenerate Type 1 follicles was higher than Type 2 in ovarian pieces preserved at $4{ }^{\circ} \mathrm{C}$, while in ovarian pieces preserved at $20^{\circ} \mathrm{C}$, the percentage of degenerate Type 2 follicles was higher. In treatments that differed from the control in percentage of MNPF (i.e. CW and SS at $20{ }^{\circ} \mathrm{C}$ for 12 and $18 \mathrm{~h}$ ), there was always a higher percentage of degenerate Type 2 follicles. 
A total of 3873 primordial (79.0\%), 766 primary (15.6\%), and 262 secondary (5.4\%) follicles were analyzed. Of the total numbers of primordial, primary, and secondary follicles, 15.0 (583/3873), 32.4 (248/766), and 27.9\% (73/262), respectively, were degenerate. Primordial follicles were less susceptible $(\mathrm{P}<0.05)$ to degeneration than primary follicles, although no other significant differences were detected in the incidence of degeneration among follicular classes.

Table 2

Mean ( S.D.) percentage of degenerate Type 1 and Type 2 follicles in the 12 treatments and control

\begin{tabular}{lcclll}
\hline Solution & Temperature $\left({ }^{\circ} \mathrm{C}\right)$ & Duration $(\mathrm{h})$ & \multicolumn{4}{l}{ Degenerate follicles (\%) } \\
\cline { 4 - 6 } & & & Type 1 & Type 2 & Total \\
\hline Control & & & $2.69 \pm 0.80^{\mathrm{a}}$ & $1.22 \pm 1.06^{\mathrm{a}}$ & $3.92 \pm 1.31$ \\
CW & 4 & 6 & $6.69 \pm 1.98^{\mathrm{a}}$ & $0.00 \pm 0.00^{\mathrm{b}}$ & $6.69 \pm 7.41$ \\
SS & 4 & 6 & $4.14 \pm 1.98^{\mathrm{a}}$ & $0.13 \pm 0.23^{\mathrm{b}}$ & $4.27 \pm 2.21$ \\
CW & 4 & 12 & $1.85 \pm 1.84^{\mathrm{a}}$ & $0.00 \pm 0.00^{\mathrm{a}}$ & $1.85 \pm 1.84$ \\
SS & 4 & 12 & $5.77 \pm 6.49^{\mathrm{a}}$ & $0.76 \pm 1.31^{\mathrm{a}}$ & $6.52 \pm 7.80$ \\
CW & 4 & 18 & $3.59 \pm 1.75^{\mathrm{a}}$ & $5.25 \pm 9.09^{\mathrm{a}}$ & $8.84 \pm 10.80$ \\
SS & 4 & 6 & $5.92 \pm 2.60^{\mathrm{a}}$ & $0.00 \pm 0.00^{\mathrm{b}}$ & $5.92 \pm 2.60$ \\
CW & 20 & $3.27 \pm 2.38^{\mathrm{a}}$ & $0.25 \pm 0.43^{\mathrm{b}}$ & $3.52 \pm 2.81$ \\
SS & 20 & 12 & $3.44 \pm 1.54^{\mathrm{a}}$ & $9.62 \pm 9.74^{\mathrm{a}}$ & $13.05 \pm 8.20$ \\
CW & 20 & 12 & $7.98 \pm 6.27^{\mathrm{a}}$ & $15.45 \pm 13.21^{\mathrm{a}}$ & $23.43 \pm 15.50$ \\
SS & 20 & 18 & $6.87 \pm 2.42^{\mathrm{a}}$ & $40.74 \pm 17.50^{\mathrm{b}}$ & $47.62 \pm 17.90$ \\
CW & 20 & 18 & $0.92 \pm 1.30^{\mathrm{a}}$ & $70.01 \pm 28.73^{\mathrm{b}}$ & $47.28 \pm 45.31$ \\
SS & 20 & $1.69 \pm 1.97^{\mathrm{a}}$ & $74.87 \pm 12.35^{\mathrm{b}}$ & $76.55 \pm 13.33$ \\
\hline
\end{tabular}

$\mathrm{CW}$, coconut water; SS, saline solution. Within a row, values with different superscripts $(a, b)$ are different $(P<0: 05)$

\section{Discussion}

This is the first report that zebu cow preantral follicles can be successfully stored in ovarian pieces at low temperatures. The percentage of MNPF in ovarian pieces stored at $4{ }^{\circ} \mathrm{C}$ for up to $18 \mathrm{~h}$ was over $90 \%$ (range 91-98\%) and similar to the control. On the other hand, when stored at $20{ }^{\circ} \mathrm{C}$, zebu preantral follicles only preserved their morphologically normal appearance for up to $6 \mathrm{~h}$. The longer duration of successful preservation at $4{ }^{\circ} \mathrm{C}$ may be due to lower cellular metabolism at the lower temperature.

Goat preantral follicles were preserved in ovarian pieces stored at $4{ }^{\circ} \mathrm{C}$ for up to $12 \mathrm{~h}$ in SS [2], up to $24 \mathrm{~h}$ in CW solution [1], and at $20^{\circ} \mathrm{C}$ for up to $4 \mathrm{~h}$ in either solution [1] and [2]. These results were consistent with those of the present study. On the other hand, one study performed with sheep ovaries had different results, with good preservation of preantral follicles at $20^{\circ} \mathrm{C}$ for up to $12 \mathrm{~h}$ in $\mathrm{CW}$ solution [3]. Perhaps sheep preantral follicles are more resistant to storage at $20^{\circ} \mathrm{C}$ than cow follicles. However, in the previous study, only histology was used to evaluate the morphological appearance of cells and tissues, and early signs of 
degeneration may have not been detected. Therefore, the use of a more sensitive method is recommended. Transmission electron microscopy was previously used to assess early degenerative changes on the structure and distribution of cellular organelles [1] and [2]. In these studies, some follicles classified as morphologically normal during histological evaluation were degenerate when assessed by transmission electron microscopy. The principal alterations observed in these degenerating follicles were a great number of vacuoles in the ooplasm, sometimes associated with rupture of the nuclear envelope, and low cytoplasm density in granulosa cells [1] and [2]. In the present study, follicles from the treatments with the best results (e.g. storage at $4{ }^{\circ} \mathrm{C}$ for $18 \mathrm{~h}$ in both solutions) were reevaluated by transmission electron microscopy and no signs of degeneration were observed in oocytes or granulosa cells.

The effect of storing ovaries at reduced temperatures has also been investigated in cattle, with particular attention to oocytes aspired from antral follicles [8] and [9]. In those studies, storage of ovaries at low temperatures $\left(4-21^{\circ} \mathrm{C}\right)$ [8] and [9] did not affect the percentage of morulae and blastocysts after in vitro maturation and fertilization of oocytes. However, the effectiveness of cold storage depended on the developmental stage of the oocytes. In vitro-matured bovine oocytes cooled at 20,10 , or $0{ }^{\circ} \mathrm{C}$ had lower fertilization, cleavage, and embryonic development rates than those maintained at $39{ }^{\circ} \mathrm{C}[10]$. Similarly, Aman and Parks [11] showed that in vitro-matured bovine oocytes were extensively damaged during storage at $4{ }^{\circ} \mathrm{C}$. This damage was specially observed at the metaphase plate, with microtubule depolymerization and chromosomal dispersion [11], and was also reported to occur with human oocytes [12]. Immature oocytes enclosed in preantral follicles may be less susceptible to damage caused by low temperature storage, as observed in this study, because most of its microtubular system is still unorganized, and its chromatin is uncondensed and protected by the nuclear envelope [13].

In the present study, the use of either a rich (coconut water) or simple solution (saline) had no significant effect on the percentage of normal follicles. These results suggested that temperature is the most important factor for the preservation of preantral follicles in ovarian pieces. Little effect of the media used was also reported when goat preantral follicles were stored at low temperatures in different solutions [1], [2] and [4]. A richer solution might not be able to improve follicular viability in this case, because the subnormal temperature and anaerobic conditions were not ideal for cellular metabolism, even if there were nutrients available.

Histological analysis of preantral follicles in the control ovaries (as well as in those treatments that did not differ from the control, i.e. $4{ }^{\circ} \mathrm{C}$ for up to $18 \mathrm{~h}$ and $20^{\circ} \mathrm{C}$ for up to $6 \mathrm{~h}$ ), 
displayed changes in the oocyte that were the first degenerative signs observed (degeneration Type 1). Similar results were also observed in sheep [3] and goat [1] and [2] preantral follicles stored at $4{ }^{\circ} \mathrm{C}$, and in fresh ovine [14], caprine [15], and bovine [16] ovaries, suggesting that this type of degeneration is commonly observed in ruminant preantral follicles. In contrast, when zebu ovaries were stored at $20^{\circ} \mathrm{C}$ for 12 or $18 \mathrm{~h}$, degeneration of granulosa cells (Type 2) was frequently observed, suggesting that this kind of degeneration was caused by storage. In these treatments, granulosa cells were disorganized and lost their contact with the oocyte. Similar findings were also reported in ovarian follicles undergoing natural [17] or induced [18] atresia. Moreover, degeneration and detachment of granulosa cells during atresia are related to apoptosis, and according to Hughes and Gorospe [19], DNA cleavage begins before any morphological signs of cellular death. It is well known that contact between granulosa cells and oocyte is essential for the growth of the oocyte; the granulosa cells contribute to the oocyte's metabolic processes [20]. In a morphological and functional study of mouse preantral follicles, Cortvrindt et al. [21] stated that follicles with a complete disconnection between oocyte and granulosa cells suffered irreversible damage. Morphological assessment of follicular integrity has been largely used to evaluate the effectiveness of the various treatments to which ovarian follicles were subjected [1], [2], [3], [15], [16] and [21]. Although it does not replace functional tests (e.g. in vitro culture), the detection of morphological alterations is good evidence of cellular damage.

In general, primordial follicles were less susceptible to degeneration than primary follicles when stored at low temperatures. Primordial follicles are quiescent, whereas primary follicles are already activated and in early growth. Although the mechanisms of primordial follicle activation are yet undefined, it is well known that oocyte and granulosa cells from primary follicles undergo fast and substantial transformations, such as granulosa cell proliferation and change in shape, oocyte growth and proliferation of cytoplasmic organelles in both cell types [22], [23] and [24]. Cells undergoing such transformations may be more sensitive to environmental factors, and thus degenerate under conditions of reduced temperature.

In conclusion, preantral follicles from zebu cows could be successfully stored in ovarian pieces at $4{ }^{\circ} \mathrm{C}$ for up to $18 \mathrm{~h}$ and at $20{ }^{\circ} \mathrm{C}$ for up to $6 \mathrm{~h}$, either in $\mathrm{CW}$ or SS. The storage of ovaries in these conditions during transportation may be very useful for optimizing the use of oocytes enclosed in preantral follicles. 
Acknowledgements

This research was partially sponsored by CNPq. The authors thank B.M. Palácio for the English correction of the manuscript.

\section{References}

[1] Silva JRV, Lucci CM, Carvalho FCA, Ba'o SN, Costa SHF, Santos RR. Effect of coconut water and Braun-Collins solutions at different temperatures and incubation times on the morphology of goat preantral follicles preserved in vitro. Theriogenology 2000;54:809-22.

[2] Carvalho FCA, Lucci CM, Silva JRV, Andrade ER, Ba'o SN, Figueiredo JR. Effect of BraunCollins and saline solutions at different temperatures and incubation times on the quality of goat preantral follicles preserved in situ. Anim Reprod Sci 2001;66:195-208.

[3] Andrade ER, Amorim CA, Matos MHT, Rodrigues APR, Silva JRV, Dode MAN, et al. Evaluation of saline and coconut water solutions in the preservation of sheep preantral follicles in situ. Small Rum Res 2002;43:235-43.

[4] Ferreira MAL, Brasil AF, Silva JRV, Andrade ER, Rodrigues APR, Figueiredo JR. Effects of storage time and temperature on atresia of goat ovarian preantral follicles held in M199, with or without indole-3-acetic acid supplementation. Theriogenology 2001;55:1607-17.

[5] Nunes JF. Utilization of coconut water as diluent for domestic animals semen. Rev Bras Reprod Anim 1998;22:109-12.

[6] Laguna LE, Nunes JF. Physical-chemical evaluation of the coconut water in the beach and dwarf varieties. Rev Bras Reprod Anim 1997;21:156.

[7] Hulshof SCJ, Figueiredo JR, Beckers JF, Bevers MM, van den Hurk R. Isolation and characterization of preantral follicles from foetal bovine ovaries. Vet Q 1994;16:78-80.

[8] Solano R, Armas R, Pupo CA, Castro FO. Short-term preservation of intrafollicular oocytes at 4 8C. Theriogenology 1994;41:299 [abstract].

[9] Schernthaner W, Schmoll F, Brem G, Schellander K. Storing bovine ovaries for $24 \mathrm{~h}$ between 15 and $218 \mathrm{C}$ does not influence in vitro production of blastocysts. Theriogenology 1997;47:297 [abstract].

[10] Azambuja RM, Kraemer DC, Westhusin ME. Effect of low temperatures on in-vitro matured bovine oocytes. Theriogenology 1998;49:1155-64.

[11] Aman RR, Parks JE. Effects of cooling and rewarming on the meiotic spindle and chromossomes of in vitro-matured bovine oocytes. Biol Reprod 1994;50:103-10.

[12] Pickering SJ, Braude PR, Johnson MH, Cant A, Currie J. Transient cooling to room temperature can cause irreversible disruption of the meiotic spindle in human oocyte. Fertil Steril 1990;54:102-8. 
[13] Matson BA, Albertini DF. Oogenesis: chromatin and microtubule dynamics during meiotic prophase. Mol Reprod Dev 1990;25:374-83.

[14] Jorio A, Mariana JC, Lahlou-Kassi A. Development of the population of ovarian follicles during the prepubertal period in D'man and Timahdite sheep. Anim Reprod Sci 1991;26:23950 .

[15] Lucci CM, Amorim CA, Rodrigues APR, Figueiredo JR, Ba'o SN, Silva JR, et al. Study of preantral follicular population in situ and after mechanical isolation from undefined breed type goats at different reproductive stages. Anim Reprod Sci 1999;56:223-6.

[16] Lucci CM, Rumpf R, Figueiredo JR, Ba'o SN. Zebu (Bos indicus) ovarian preantral follicles: morphological characterization and development of an efficient isolation method. Theriogenology 2002;57:1467-83.

[17] Devine PJ, Payne CM, McCuskey MK, Hoyer PB. Ultrastructural evaluation of oocytes during atresia in rat ovarian follicles. Biol Reprod 2000;63:1245-52.

[18] Bailey KI, O’Brien Jr WD, Dunn F. Ultrasonically induced morphological damage to mouse ovaries. Ultrasound Med Biol 1983;9:25-31.

[19] Hughes Jr FM, Gorospe WC. Biochameical identification of apoptosis (programmed cell death) in granulosa cells: evidence for a potential mechanism underlying follicular atresia. Endocrinology 1991; 129:2415-22.

[20] Eppig JJ. Intercommunications between mammalian oocytes and companion somatic cells. Bioessays 1991;13:569-74.

[21] Cortvrindt R, Smitz J, Van Steirteghem AC. A morphological and functional study of the effect of slow freezing followed by complete in-vitro maturation of primary mouse ovarian follicles. Hum Reprod 1996;11:2648-55.

[22] Hyttel P, Fair T, Callensen H, Greve T. Oocyte growth, capacitation and final maturation in cattle. Theriogenology 1997;47:23-32.

[23] Fair T, Hulshof SCJ, Hyttel P, Greve T, Boland M. Oocyte ultrastructure in bovine primordial to early tertiary follicles. Anat Embryol 1997;195:327-36.

[24] Lucci CM, Silva JRV, Carvalho FCA, Figueiredo JR, Báo SN. Light microscopical and ultrastructural characterization of goat preantral follicles. Small Rum Res 2001;41:61-9. 